\title{
Determination of manganese in rat blood samples based on ionic liquid-liquid extraction and chelation therapy for evaluation of manganese toxicity in rats
}

\author{
S. Jamilaldin Fatemi ${ }^{\mathrm{a}, \mathrm{w}}$, Tayyebeh Zandevakilia, Fatemeh Khajoee Nejad ${ }^{\mathrm{a}}$, Marziyeh \\ Iranmanesh $^{\mathrm{b}}$ and Mohammad Faghihi Zarandic \\ ${ }^{a}$ Department of Chemistry, Shahid Bahonar University of Kerman, Kerman, Iran \\ ${ }^{b}$ Department of Chemistry, Kerman Branch, Islamic Azad University, Kerman, Iran \\ ${ }^{c}$ Department of Foreign Languages, Shahid Bahonar University of Kerman, Kerman, Iran
}

\section{A R T I C L E I N F O :}

Received 22 Aug 2021

Revised form 28 Oct 2021

Accepted 23 Nov 2021

Available online 28 Dec 2021

Keywords:

Chelators,

Red blood cells,

Toxicity,

Ionic liquid-liquid extraction,

Flame atomic absorption spectrometry

\begin{abstract}
A B S T R A C T
In this study, the manganese ions were extracted in the blood of rats based on desferrioxamine (DFO), deferasirox (DFX) and deferiprone (DFP) as chelators (ligands) by ionic liquid-liquid phase extraction method (ILLEM) before being determined by F-AAS. Also, the toxic effects of manganese on blood serum and hematology parameters such as: $\mathrm{RBC}$, WBC, HGB, PLT and HCT were investigated. Male Wistar rats were randomly divided into control and toxic groups. Manganese chloride was administrated orally in low and high doses. Orally (deferasirox and deferiprone) or intraperitoneally (desferrioxamine) for 2 weeks. Results showed that exposure to manganese significantly increased both counts of hematology parameters and concentration of this metal ion in serum compared to the control group. By procedure, manganese was chelated with ligands in the blood of rats and then the hydrophobic ionic liquid (IL, [HMIM][PF6]) was added to blood samples. After shaking and centrifuging, the upper liquid phase was separated by an auto-sampler and manganese loaded in a mixture of IL/ligand was settled down in the bottom of the conical tube. The manganese ions were back-extracted from IL phase and the remained acid solution was determined with F-AAS. The linear range, LOD and enrichment factor for $10 \mathrm{~mL}$ of blood rats were obtained 25- $180 \mu \mathrm{g} \mathrm{L}^{-1}, 6.5 \mu \mathrm{g} \mathrm{L} \mathrm{L}^{-1}$ and 19.92, respectively. By chelation therapy extra manganese ions were removed from human serum and the normal hematology parameters were achieved.
\end{abstract}

\section{Introduction}

Trace elements like manganese are essential for normal development and body function across the life span, and are widely distributed in the tissues. Manganese is required for normal amino acid, lipid, protein, and carbohydrate metabolisms. Enzyme families that are Mn-dependent include

\footnotetext{
*Corresponding Author: S. Jamilaldin Fatemi

Email: fatemijam@uk.ac.ir

https://doi.org/10.24200/amecj.v4.i04.160
}

oxidoreductases, transferases, hydrolases, lyases, isomerases, and ligases. A manganese deficiency causes improper organism function, but toxicity results if $\mathrm{Mn}$ is present in excessive amounts $[1,2]$. Concentrations of metal in erythrocytes may be a good indicator of tissue accumulation since red blood cells account for about $60-80 \%$ of the metal found in whole blood [3-5]. Manganese leaving the enterocyte and entering the circulation bound to transferrin, may bind to transferrin receptors on erythroid cells. The erythroid cell 
potentially may incorporate manganese into the porphyrin ring in place of iron, therefore producing a manganese protoporphyrin instead of haem [6]. Mn is known to be transported by the transferrin receptor (TfR) and/or divalent metal transporter (DMT1) [7]. Both transporters have been identified in the RBC. Whole blood, serum and plasma manganese are the readily available biomarkers of manganese status in humans. The strength of the observed correlation between blood manganese concentrations and manganese exposure concentrations often depends on the magnitude and duration of exposure. In some studies, whole blood manganese concentrations correlate positively with exposure to manganese [8]. In other cases, blood manganese concentrations in exposed workers remain in the normal adult range (4-14 $\left.\mu \mathrm{g} \mathrm{L}^{-1}\right)$, and urine and hair manganese concentrations do not differ between exposed and non-exposed workers [9]. In severe cases of $\mathrm{Mn}$ poisoning, chelation therapy has been recommended in order to reduce the body burden of Mn. Chelation therapy that could be carried out as a single and/or combined therapy involves the use of chelating drugs that bind metal for the treatment of potentially fatal conditions $[10,11]$. In this investigation, we studied the effect of $\mathrm{MnCl}_{2}$ exposure in low and high doses on blood serum and hematology parameters in male Wistar rats. Deferasirox (4-[3,5-bis (2- hydroxyphenyl)-1,2,4triazol-1-yl]-benzoic acid, or ICL670) is a tridentate chelator and was first reported by Heinz et al [12]. Deferiprone (1,2-dimethyl-3-hydroxypyrid-4one) is a bidentate chelator that was used in the detoxification of metals and desferrioxamine $\left(N^{\prime}\right.$ $\{5$-[acetyl(hydroxy) amino]pentyl $\}-N-[5-(\{4-[(5-$ aminopentyl)(hydroxy)amino]-4-oxobutanoyl \}amino)pentyl]- $N$-hydroxysuccinamide) is a hexadentate chelator. Manganese (Mn) used in human body. Manganese ions enter to human body from waters/ foods (rice, apple, wheat, beans, lettuce) and cause the different diseases. [13]. The high values of manganese exist in spinach and tea leaves in ranges of 10-100 $\mathrm{mg} \mathrm{kg}^{-1}$ [14]. The manganese values in water has found less than $100 \mu \mathrm{g} \mathrm{L}^{-1}$ at $\mathrm{pH}$
7 and the oxidized forms archived in low $\mathrm{pH}[15,16]$. Normal values of manganese in blood samples have found from 1 to $14.5 \mu \mathrm{g} \mathrm{L} \mathrm{L}^{-1}$ [17]. The extra dosage of manganese has toxicity effect and caused to many diseases such as, memory impairment, dysfunction on liver, renal and CNS. So, manganese in various source such as water and blood samples must be measured by analytical procedures. As toxicity effect of manganese, it is caused to increase the neutrophil count cells and decrease the red blood cells. So, the various analytical techniques such as, flame atomic absorption spectrometry [18], cation exchange chromatography—sector field inductively coupled plasma mass spectrometry [19], the inductively coupled plasma mass spectrometryMS [20] was used for determining of manganese in biological samples. Also, due to the trace concentration of manganese, and difficulty matrixes, the sample treatment used before sample analysis. Many sample treatments such as, the liquid-liquid extraction [21], the deep eutectic solvent extraction [22], the column graphene oxide-based solid phase extraction [23] were used for manganese extraction in blood samples.

In this research, manganese ions were extracted in blood of rats based on DFO, DFX and DFP chelators by IL-LEM procedure and the manganese concentration in rat blood samples was determined by the F-AAS. Also, the toxic effects of manganese on blood serum and hematology parameters such as: RBC, WBC, HGB, PLT and HCT were investigated.

\section{Experimental}

\subsection{Rats preparation}

The Ethics Committee at Medical Sciences, The University of Kerman, approved the research protocol. Male Wistar rats were purchased from Kerman Neuroscience Research Center, Kerman, Iran. At the time of use the rats were 7-8 weeks old, weighing $245 \pm 4 \mathrm{~g}$ (mean \pm SEM.). All animals were housed in well-cleaned sterilized cages maintained in a room under controlled conditions of temperature $\left(23 \pm 2{ }^{\circ} \mathrm{C}\right)$ and illumination (12-h light; 12-h darkness; darkness: 7 p.m. -7 a.m.) and had free access to a standard diet and water. 


\subsection{Reagents}

The desferrioxamine (DFO, CAS N.: 138-147), deferasirox (DFX, CAS N.: 201530-41-8) and deferiprone (DFP, CAS N.: 30652-11-0) as chelating agents (ligands) were purchased from Sigma Aldrich, Germany. 1-Hexyl-3methylimidazolium hexafluorophosphate (IL, 97.0\% HPLC grade; CAS N.: 304680-35-1) was prepared from Sigma Aldrich, Germany. Other materials were prepared from Merck Chemical Co. (Darmstadt, Germany). The standard solution for manganese were prepared by dissolving of $1.0 \mathrm{~g}$ of $\mathrm{Mn}\left(\mathrm{NO}_{3}\right)_{2}$ in deionized water (DW, $\left.1 \mathrm{Li}\right)$. The working standard solutions for calibration of manganese were daily prepared by diluting of standard solutions (1000 mg L $\left.\mathrm{m}^{-1}\right)$ with DW (Millipore, USA). All the glass and tubes were cleaned by $\% 10$ nitric acid (v/v) for two days and then washed by DW. The standard reference materials (1640a; SRM) for manganese in water $\left(40.39 \pm 0.36 \mu \mathrm{g} \mathrm{L}^{-1}\right)$ was used.

\subsection{Instrumental}

Flame atomic absorption spectrometer with a double beam accessory (F-AAS, GBC 906, Aus.) based on air-acetylene $\left(\mathrm{C}_{2} \mathrm{H}_{2}\right)$, the $\mathrm{D}_{2}$ and $\mathrm{HCL}$ lampas was used. The limits of detection (LOD) and linear range was achieved $0.16 \mathrm{mg} \mathrm{L}^{-1}$ and 0.5-3.6 $\mathrm{mg} \mathrm{L}^{-1}$, respectively by the FAAS. The HCL light of manganese was optimized by two screws (Hor. S and Ver. S) and the wavelength of $279.5 \mathrm{~nm}$ (slit of $0.2 \mathrm{~nm} ; 5 \mathrm{~mA}$ ) was selected for
F-AAS. After sample treatment, $1 \mathrm{~mL}$ of water and blood samples were injected to burner of FAAS by the auto-sampler. The working range for F-AAS was obtained $0.2-3.8 \mathrm{mg} \mathrm{L}^{-1}$. The validation of results was obtained by the graphite furnace atomic absorption spectrophotometer (GF-AAS, GBC, Aus.) for manganese analysis in blood samples. The $\mathrm{pH}$ of the samples was measured by Omega $\mathrm{pH}$ meter (USA). The shaker (Grant, U.K) and centrifuge (speed 3000$5000 \mathrm{rpm} x \mathrm{~g}$, Germany) was used for extraction/ separation of manganese from blood samples.

\subsection{Chelation therapy design}

In this study, manganese chloride $\left[\mathrm{MnCl}_{2}\right.$ (LD50: $\left.\left.1715 \mathrm{mg} \mathrm{kg}^{-1}\right)\right]$ at two doses of $30 \mathrm{mg} \mathrm{kg}^{-1}$ body weight (low dose) and $60 \mathrm{mg} \mathrm{kg}^{-1}$ body weight (high dose) was given to the drinking groups for 3 months followed by an early administration of chelating agent. Study population consisted of 95 rats that were housed in groups of five per cage. We assigned them randomly to control (5 rats) and treated groups [high dose (45 rats) and low dose (45 rats)]. After 90 days, chelation therapy was carried out after Mn application. Treated animals were classified as follows (Table 1): before chelation therapy (5 rats), without chelation therapy [vehicle oral (5 rats) and intraperitoneally (5 rats)], single therapy (15 rats) and combined therapy (15 rats) for both low and high doses. Chelators were given orally (DFX and DFP) and intraperitoneally (DFO) as single and combined therapies. Doses of DFX,

Table 1. Classification of rat animals for further analysis

Treated groups (90):

Before chelation therapy

Without chelation therapy (Vehicle)

Single therapy

Combined therapy
Vehicle oral

Vehicle intraperitonealy DFX (30 $\mathrm{mg} \mathrm{kg}^{-1}$ body weight) DFO (30 $\mathrm{mg} \mathrm{kg}^{-1}$ body weight) L1 (60 $\mathrm{mg} \mathrm{kg}^{-1}$ body weight) DFX (15 $\mathrm{mg} \mathrm{kg}^{-1}$ body weight)+DFO (15 $\mathrm{mg} \mathrm{kg}^{-1}$ body weigh DFX (15 $\mathrm{mg} \mathrm{kg}^{-1}$ body weight $)+\mathrm{L} 1$ (30 $\mathrm{mg} \mathrm{kg}^{-1}$ body weight) DFO (15 $\mathrm{mg} \mathrm{kg}^{-1}$ body weight $)+\mathrm{L} 1$ (30 $\mathrm{mg} \mathrm{kg}^{-1}$ body weight) 
DFP and DFO were 30, 60 and $30 \mathrm{mg} \mathrm{kg}^{-1}$ body weight, respectively (Table 1). Chelators were given immediately after $\mathrm{Mn}$ application during 2 weeks. After chelation therapy, rats were sacrificed by exsanguinations from abdominal aorta and their blood was collected for analysis.

\subsection{Sample collection and analysis procedure}

The full blood count sample was collected into a citrate tube (Tek Lab, Catalogue No. K-100LS). Hematology parameters such as RBC $\left(10^{6} / 1\right)$, WBC $\left(10^{3} \mathrm{~L}^{-1}\right)$, HGB $\left(\mathrm{g} \mathrm{dL}^{-1}\right)$, PLT $\left(10^{3} \mathrm{~L}^{-1}\right)$ and HCT $(\%)$ were measured in whole blood by countering device (fluorescent flow cytometry technology (Sysmex KX-21N) in hematology lab.

By the IL-LEM procedure, the DFO, DFX and DFP chelators mixed with IL and used for speciation and extraction of Mn ions in rat blood samples (Fig.1). The chelators dispersed in $10 \mathrm{~mL}$ of standard manganese solution (25- $\left.180 \mu \mathrm{g} \mathrm{L}^{-1}\right)$ and rat blood samples, after chelation and extraction Mn ions, the hydrophobic ionic liquid ([HMIM] [PF6];100 mg) was added to samples and diluted with acetone. In fact, the Mn ions was extracted by coordination bond of nitrogen at optimized $\mathrm{pH}(98 \%)$, but at higher $\mathrm{pH}$, manganeseions precipitated $\left(\mathrm{Mn}(\mathrm{OH})_{2}\right)$. The manganese chelated with the DFO, DFX and DFP chelators and separated from samples by hydrophobic ionic liquid ([HMIM] [PF6]) in end of conical tube after centrifuging for $5 \mathrm{~min}$ at 3500 rpm. After removing upper blood/serum phase, manganese ions were back-extracted from the $\mathrm{DFO} / \mathrm{IL}, \mathrm{DFX} / \mathrm{IL}$ and DFP/IL into aqueous phase with $0.3 \mathrm{~mL}$ of $\mathrm{HNO}_{3}$ solutions $(0.2 \mathrm{M})$. Finally, the resulting solution was determined by F-AAS after dilution with DW up to $0.5 \mathrm{~mL}$. The linear range for manganese was $25-180 \mu \mathrm{g} \mathrm{L}^{-1}$ or $0.025-0.18$ $m g \mathrm{~L}^{-1}$ by the IL-LEM procedure.

\subsection{Statistical analysis}

The statistical package for the sciences (SPSS, Bristol, England) version 18 was used to process the data. All comparisons among the groups were analyzed with a one-way analysis of variance (ANOVA) followed by LSD test for multiple comparisons. Data were reported as the mean $\pm \mathrm{SEM}$. In all comparisons, $\mathrm{p}<0.05$ was the criterion for statistical significance.

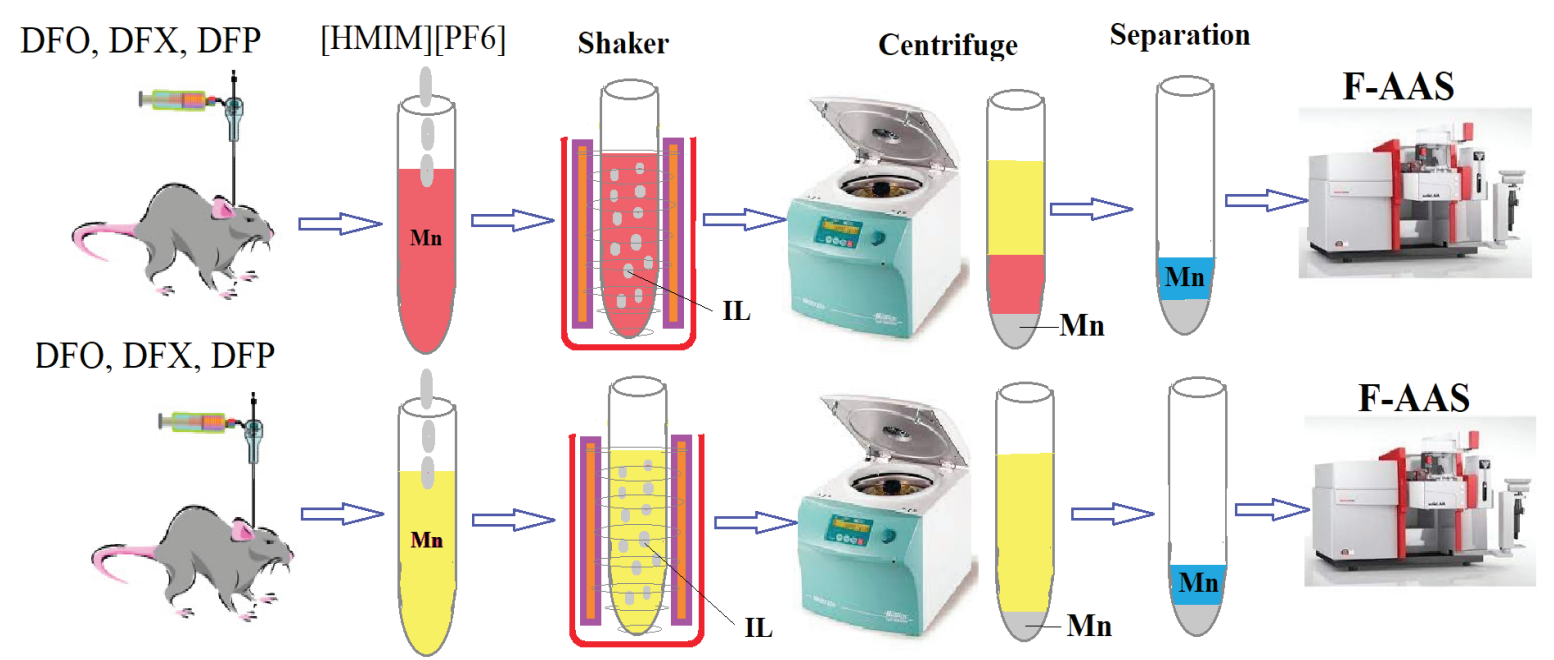

Fig.1. Determination of manganese in the rat blood/serum based on chelators by the IL-LEM procedure coupled to F-AAS 
Table 2. Bodyweights over 90 days for rats in different groups (all data are expressed as the mean \pm SEM)

\begin{tabular}{llll}
\hline Group & Control & $\begin{array}{l}\text { Low dose } \\
\text { drinking of manganese }\end{array}$ & $\begin{array}{l}\text { High dose } \\
\text { drinking of manganese }\end{array}$ \\
\hline Initial body weight $(\mathrm{g})$ & $242.21 \pm 8.62$ & $249.80 \pm 2.91$ & $244.61 \pm 4.20$ \\
Final body Weight $(\mathrm{g})$ & $297.20 \pm 7.46$ & $299.60 \pm 4.55$ & $286.61 \pm 7.95$ \\
\hline
\end{tabular}

\section{Results and Discussion}

\subsection{Symptoms}

Over 90 days, results indicated that difference weight between initial and final body weight, decreased in both the high and low doses groups compared to the control group (Table 2). Furthermore, toxicity symptoms such as: skin reaction, black spots on liver and bright lung appeared.

\subsection{Hematology parameters}

The hematology parameters are shown in Table 3 and 4. Compared to each respective control group, a significant enhance in HGB count was observed in both low and high doses groups. The RBC, WBC, PLT and HCT counts enhanced significantly in the high dose group (Table 3 and 4, Fig. 2). In order to investigate the effect of passing time in removing
Mn from the body spontaneously, one group was treated as without chelation therapy (vehicle). Since there were no significant differences between the vehicle and before chelation therapy groups, results of chelation therapy were compared to each respective vehicle group. After chelation therapy, the RBC count significantly reduced by DFO+DFX in low dose group and DFO in high dose group. The HGB count significantly reduced by DFX, DFP(L1) and DFO+DFX in low dose group and DFO, DFP (L1), DFX, DFO+DFP (L1), DFO+DFX and DFX+DFP(L1) in high dose group. The PLT count by DFO and DFX+DFP(L1), also HCT count by DFO and DFO+DFP (L1) significantly reduced in high dose group (Table 3 and 4, Fig. 3). (The level of significance in all tests was set as $\mathrm{p}<0.05$ )

Table 3. Hematology parameters in low-dose groups (all data are expressed as the mean \pm SEM)

\begin{tabular}{|c|c|c|c|c|c|c|c|c|c|}
\hline Group & Control & $\begin{array}{l}\text { Before } \\
\text { chelation } \\
\text { therapy }\end{array}$ & Vehicle & $\begin{array}{l}\text { Chelation } \\
\text { therapy } \\
\text { DFX }\end{array}$ & $\begin{array}{l}\text { Chelation } \\
\text { therapy } \\
\text { DFP } \\
\text { (L1) }\end{array}$ & $\begin{array}{l}\text { Chelation } \\
\text { therapy } \\
\text { DFO }\end{array}$ & $\begin{array}{l}\text { Chelation } \\
\text { therapy } \\
\text { DFO+DFP } \\
\text { (L1) }\end{array}$ & $\begin{array}{l}\text { Chelation } \\
\text { therapy } \\
\text { DFX+DFO }\end{array}$ & $\begin{array}{l}\text { Chelation } \\
\text { therapy } \\
\text { DFX+DFP } \\
\text { (L1) }\end{array}$ \\
\hline $\begin{array}{l}\text { RBC } \\
\left(10^{6} \mathrm{~L}^{-1}\right)\end{array}$ & $7.24 \pm 0.25$ & $7.28 \pm 0.11$ & $7.91 \pm 0.39$ & $7.58 \pm 0.33$ & $7.28 \pm 0.42$ & $7.75 \pm 0.11$ & $7.88 \pm 0.14$ & $6.98 \pm 0.57$ & $7.63 \pm 0.16$ \\
\hline $\begin{array}{l}\text { WBC } \\
\left(10^{3} \mathrm{~L}^{-1}\right)\end{array}$ & $7.42 \pm 0.43$ & $8.60 \pm 1.94$ & $9.79 \pm 1.94$ & $9.94 \pm 0.59$ & $11.10 \pm 1.14$ & $9.80 \pm 0.84$ & $9.80 \pm 1.64$ & $12.25 \pm 1.22$ & $8.04 \pm 0.83$ \\
\hline $\begin{array}{l}\mathrm{HGB} \\
\left(\mathrm{g} \mathrm{dL}^{-1}\right)\end{array}$ & $11.96 \pm 0.29$ & $13.02 \pm 0.75$ & $12.75 \pm 0.38$ & $11.54 \pm 0.89$ & $11.35 \pm 0.03$ & $12.77 \pm 0.14$ & $12.15 \pm 0.43$ & $10.80 \pm 2.18$ & $12.18 \pm 0.33$ \\
\hline $\begin{array}{l}\text { PLT } \\
\left(10^{3} \mathrm{~L}^{-1}\right)\end{array}$ & $501.79 \pm 45.53$ & $680.02 \pm 47.69$ & $663.20 \pm 45.28$ & $782.00 \pm 37.83$ & $828.00 \pm 60.44$ & $654.20 \pm 69.69$ & $691.40 \pm 48.52$ & $579.40 \pm 153.65$ & $658.80 \pm 71.39$ \\
\hline HCT (\%) & $39.02 \pm 1.21$ & $37.39 \pm 0.20$ & $38.62 \pm 1.16$ & $37.70 \pm 1.55$ & $37.62 \pm 1.72$ & $41.00 \pm 0.26$ & $38.96 \pm 0.67$ & $35.68 \pm 2.73$ & $39.42 \pm 0.59$ \\
\hline $\begin{array}{l}\text { Mn } \\
\text { concentration } \\
\left(\mathrm{mg} \mathrm{L}^{-1}\right)\end{array}$ & $1.28 \pm 0.10$ & $1.95 \pm 0.15$ & $1.79 \pm 0.22$ & $1.32 \pm 0.14$ & $1.08 \pm 0.12$ & $1.01 \pm 0.15$ & $1.02 \pm 0.20$ & $1.34 \pm 0.17$ & $1.19 \pm 0.07$ \\
\hline
\end{tabular}

ANOVA analysis shows $\mathrm{p}$ value in all of treatment groups in comparison to vehicl 
Table 4. Hematology parameters in high-dose groups (all data are expressed as the mean \pm SEM).

\begin{tabular}{|c|c|c|c|c|c|c|c|c|c|}
\hline Group & Control & $\begin{array}{l}\text { Before } \\
\text { chelation } \\
\text { therapy }\end{array}$ & Vehicle & $\begin{array}{c}\text { Chelation } \\
\text { therapy } \\
\text { DFX }\end{array}$ & $\begin{array}{c}\text { Chelation } \\
\text { therapy } \\
\text { L1(DFP) }\end{array}$ & $\begin{array}{c}\text { Chelation } \\
\text { therapy } \\
\text { DFO }\end{array}$ & $\begin{array}{c}\text { Chelation } \\
\text { therapy } \\
\text { DFO+ } \\
\text { (DFP) L1 }\end{array}$ & $\begin{array}{c}\text { Chelation } \\
\text { therapy } \\
\text { DFX+DFO }\end{array}$ & $\begin{array}{c}\text { Chelation } \\
\text { therapy } \\
\text { DFX+L1 }\end{array}$ \\
\hline $\begin{array}{l}\mathrm{RBC} \\
\left(10^{6} \mathrm{~L}^{-1}\right)\end{array}$ & $7.24 \pm 0.25$ & $8.04 \pm 0.12$ & $8.30 \pm 0.83$ & $8.08 \pm 0.15$ & $7.92 \pm 0.70$ & $7.30 \pm 0.21$ & $7.87 \pm 0.30$ & $7.74 \pm 0.18$ & $8.41 \pm 0.18$ \\
\hline $\begin{array}{l}\text { WBC } \\
\left(10^{3} \mathrm{~L}^{-1}\right)\end{array}$ & $7.42 \pm 0.43$ & $11.22 \pm 1.44$ & $10.74 \pm 1.13$ & $10.76 \pm 1.40$ & $15.28 \pm 2.40$ & $11.56 \pm 1.38$ & $9.42 \pm 1.02$ & $11.32 \pm 1.08$ & $8.74 \pm 1.41$ \\
\hline $\begin{array}{l}\text { HGB } \\
\left(\mathrm{g} \mathrm{dL}^{-1}\right) \\
\end{array}$ & $11.96 \pm 0.29$ & $14.27 \pm 0.22$ & $13.80 \pm 0.22$ & $12.34 \pm 0.39$ & $12.68 \pm 0.20$ & $11.50 \pm 0.46$ & $12.38 \pm 0.29$ & $12.17 \pm 0.32$ & $12.84 \pm 0.29$ \\
\hline $\begin{array}{l}\text { PLT } \\
\left(10^{3} \mathrm{~L}^{-1}\right)\end{array}$ & $501.79 \pm 145.53$ & $824.00 \pm 48.12$ & $806.75 \pm 42.74$ & $630.25 \pm 56.54$ & $800.40 \pm 46.70$ & $623.00 \pm 68.40$ & $806.00 \pm 67.66$ & $723.66 \pm 42.03$ & $594.25 \pm 140.02$ \\
\hline $\begin{array}{l}\text { HCT } \\
(\%) \\
\end{array}$ & $39.02 \pm 1.21$ & $40.30 \pm 0.58$ & $40.95 \pm 0.88$ & $42.85 \pm 0.70$ & $40.86 \pm 0.59$ & $38.08 \pm 1.10$ & $38.95 \pm 0.67$ & $39.70 \pm 0.63$ & $42.60 \pm 0.96$ \\
\hline $\begin{array}{l}\text { Mn } \\
\text { concentration } \\
\left(\mathrm{mg} \mathrm{L}^{-1}\right)\end{array}$ & $1.28 \pm 0.10$ & $2.03 \pm 0.26$ & $1.32 \pm 0.14$ & $1.32 \pm 0.14$ & $1.42 \pm 0.05$ & $1.14 \pm 0.16$ & $1.23 \pm 0.14$ & $1.28 \pm 0.21$ & $1.18 \pm 0.09$ \\
\hline
\end{tabular}

ANOVA analysis shows $p$ value in all of treatment groups in comparison to vehicl
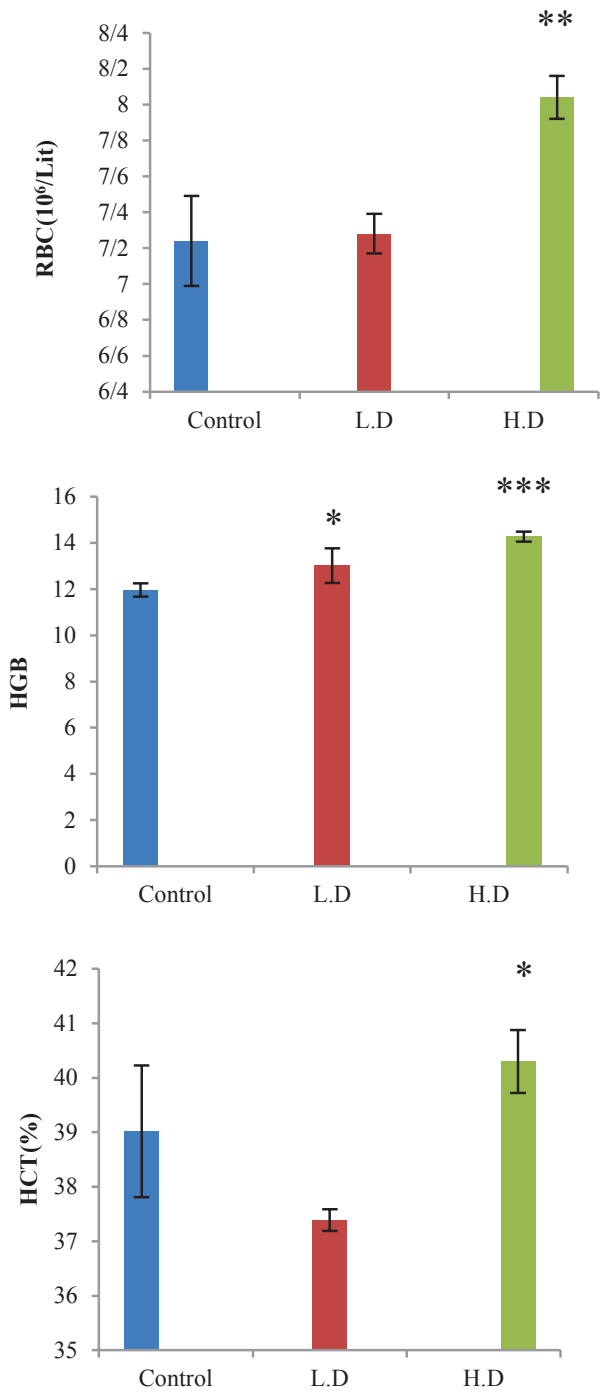
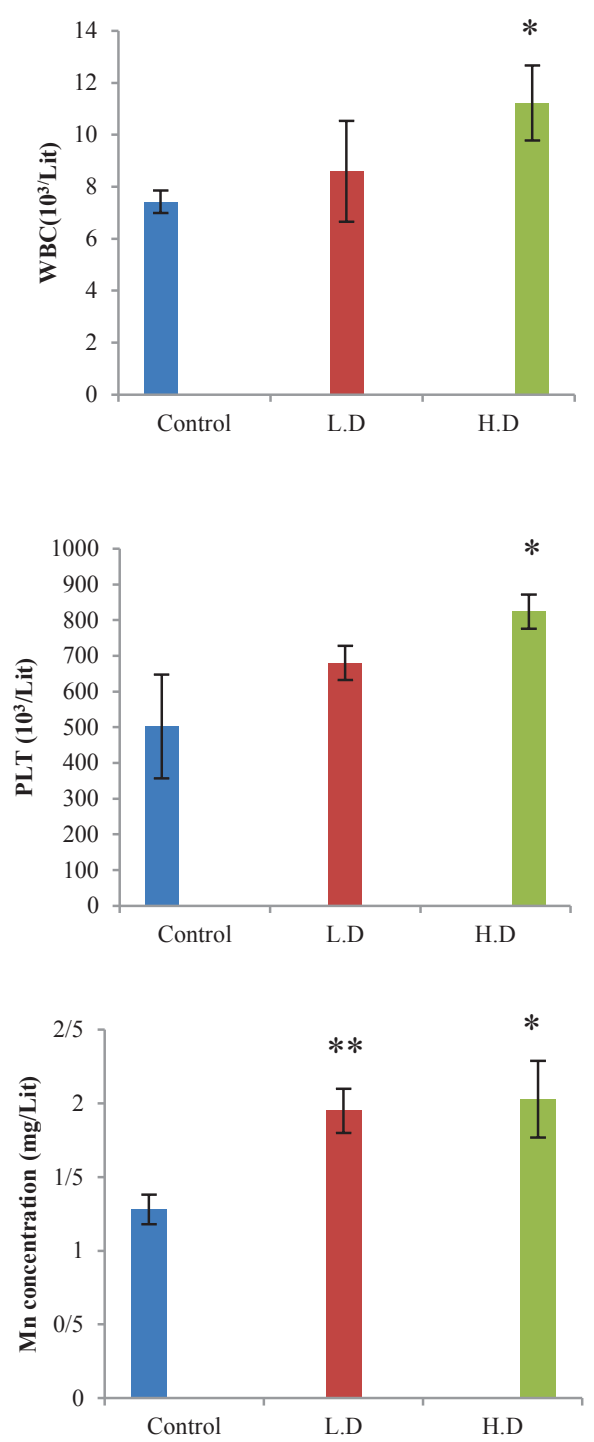

Fig. 2. Hematology parameters and Mn concentrations in control, high and low doses of $\mathrm{Mn}$ administration (Before chelation therapy), ${ }^{*} \mathrm{p}<0.05, * * \mathrm{p}<0.01, * * * \mathrm{p}<0.001$ as compared to control. 

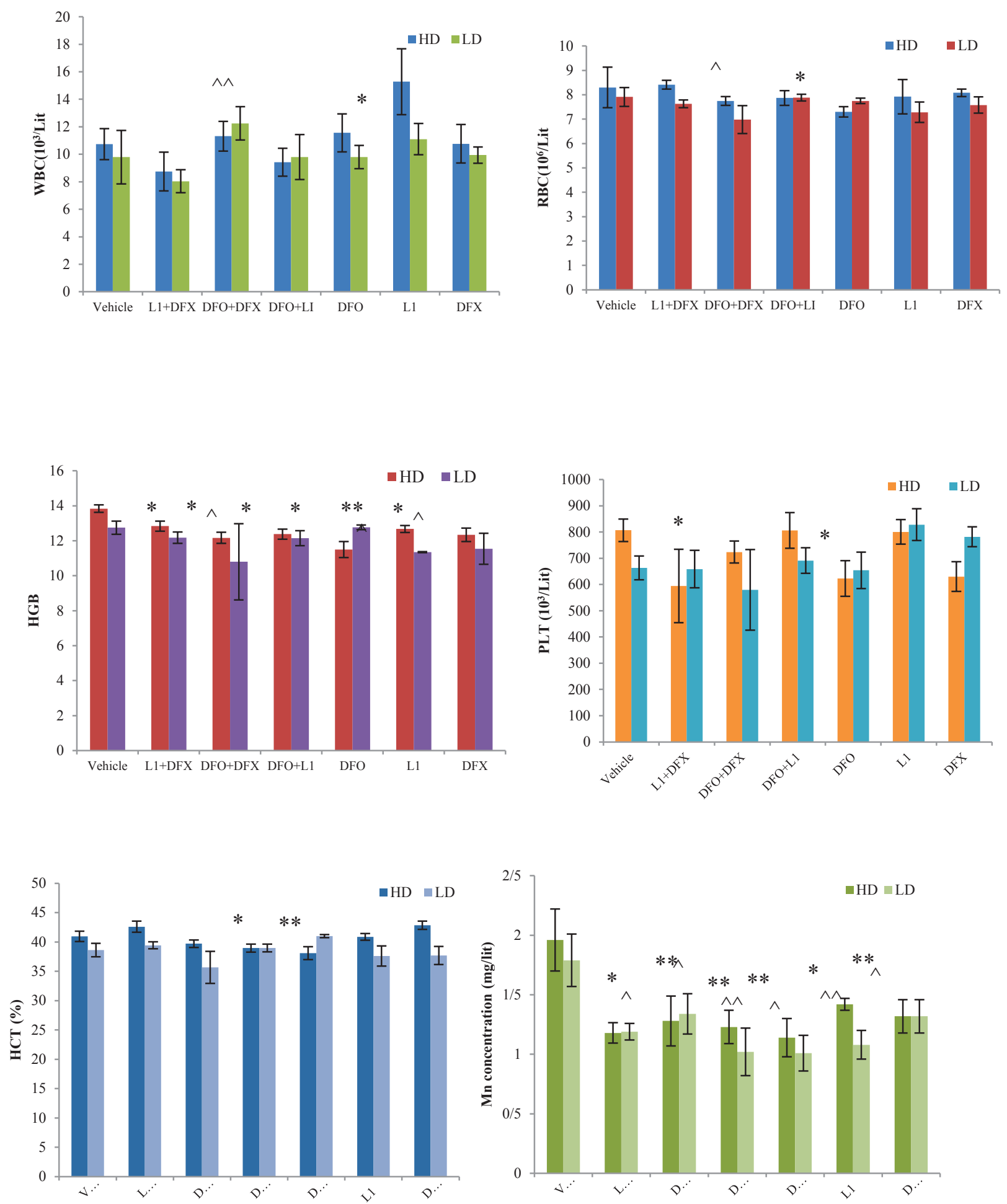

Fig. 3. Hematology parameters and concentrations of $\mathrm{Mn}$ in Vehicle and treated groups after chelation therapy, ${ }^{*} \mathrm{p}<0.05,{ }^{* *} \mathrm{p}<0.01,{ }^{* * *} \mathrm{p}<0.001$ significantly different from $H D$ vehicle and ${ }^{\wedge} \mathrm{p}<0.05,{ }^{\wedge} \mathrm{p}<0.01,{ }^{\wedge \wedge} \mathrm{p}<0.001$ significantly different from $\mathrm{LD}$ vehicle, by one-way ANOVA followed by LSD's multiple comparison test 


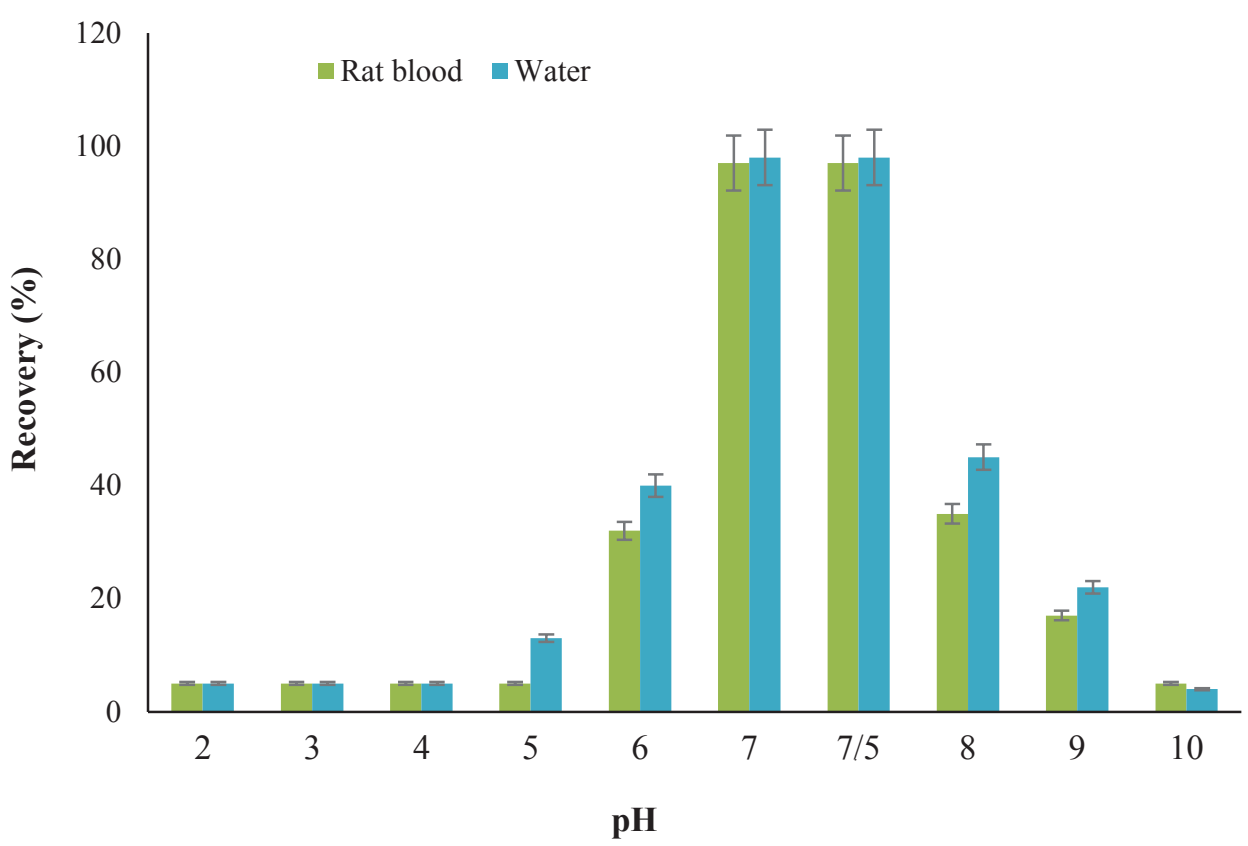

Fig.4. The effect of $\mathrm{pH}$ on manganese extraction by IL-LE method

\subsection{Mn concentration}

Administration of manganese chloride in both of low and high doses groups caused a significant increase in concentration of Mn (Table 3 and 4, Fig. 2). After chelation therapy, all chelatores significantly decreased the level of $\mathrm{Mn}$ in both low and high doses groups. Although DFO was more effective chelator (Table 3 and 4, Fig. 3)

\subsection{Optimization of extraction parameters}

For efficient extraction for manganese in blood samples, the effect of parameters such as the amount of ligand, the $\mathrm{pH}$, the Ionic liquids, the shaking and centrifuging time, the sample volume and the interferences ions were studied and optimized.

\subsection{1.pH effect}

The effect of $\mathrm{pH}$ on extraction of manganese in water and rat blood samples must be optimized. The $\mathrm{pH}$ effect on the manganese complexation by the DFO, DFX and DFP chelators. So, the various $\mathrm{pH}$ between 2 - 11 was evaluated for the Mn extraction in rat blood samples. The $\mathrm{pH}$ was controlled by a buffer solution. The result showed, the high recovery based on chelators for manganese value between $25-180 \mu \mathrm{g} \mathrm{L}^{-1}$ was obtained at $\mathrm{pH}$ of 7. The recoveries were decreased for $\mathrm{Mn}$ at $\mathrm{pH}$ ranges less than 7 and more than 8.0. So, the $\mathrm{pH}$ of 7.0-7.5 were selected for extraction of manganese in waters and rat blood samples by the IL-LEM procedure (Fig. 4).

\subsubsection{Optimization of DFO, DFX and DFP chelators}

The concentration of chelators is main parameters for manganese extraction which must be optimized by the IL-LE procedure. For optimizing, $0.1 \times 10^{-6}-$ $0.9 \times 10^{-6} \mathrm{~mol} \mathrm{~L}^{-1}$ of DFO was used in the rat blood sample. The results showed that, by increasing ligand concentration up to $0.6 \times 10^{-6} \mathrm{~mol} \mathrm{~L}^{-1}$, the recoveries are also increased (Fig. 5). So, the amount of chelating agent (DFO) between 0.6-0.9 $\mu \mathrm{mol} \mathrm{L} \mathrm{L}^{-1}$ had high recovery and $0.7 \mu \mathrm{mol} \mathrm{L}^{-1}$ was found the best amount for Mn extraction. The DFX and DFP have almost used with the similar range between 0.6-0.9 $\mu \mathrm{mol} \mathrm{L}^{-1}$. 


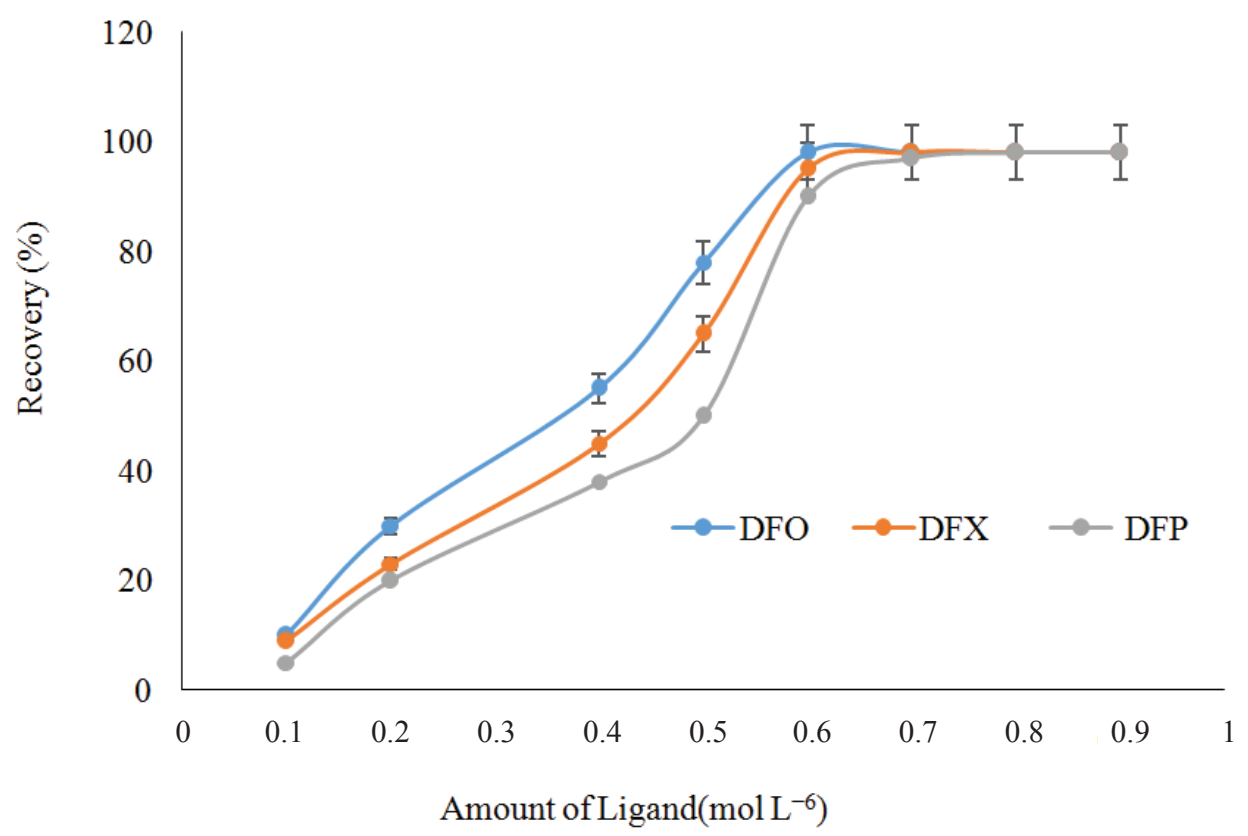

Fig. 5. The effect of ligand on manganese extraction by IL-LE method

\subsubsection{Optimization of sample volume and eluent}

The sample volume of rat blood samples and the standard solution was evaluated from $1.0 \mathrm{~mL}$ to $25 \mathrm{~mL}$ for Mn concentration between 25-180 $\mu \mathrm{g}$ $\mathrm{L}^{-1}$. The results showed us the efficient extraction was obtained for $10 \mathrm{~mL}$ of rat blood samples at $\mathrm{pH}$ 7-7.5 (Fig. 6). In-addition, the effect of eluent on manganese extraction based on ligand/IL (DFO,
DFX and DFP/IL) were evaluated. At low $\mathrm{pH}$, the covalent bond between the manganese and nitrogen group was break-down and released the Mn ions into acid phase. So, the acid solutions $\left(\mathrm{HCl}, \mathrm{HNO}_{3}\right.$, $\mathrm{H}_{2} \mathrm{SO}_{4}$ ) were used for back-extraction process in blood and water samples. The results showed, the efficient extraction was obtained by $\mathrm{HNO}_{3}(0.2 \mathrm{M}$, $0.3 \mathrm{~mL}$ ) (Fig. 7).

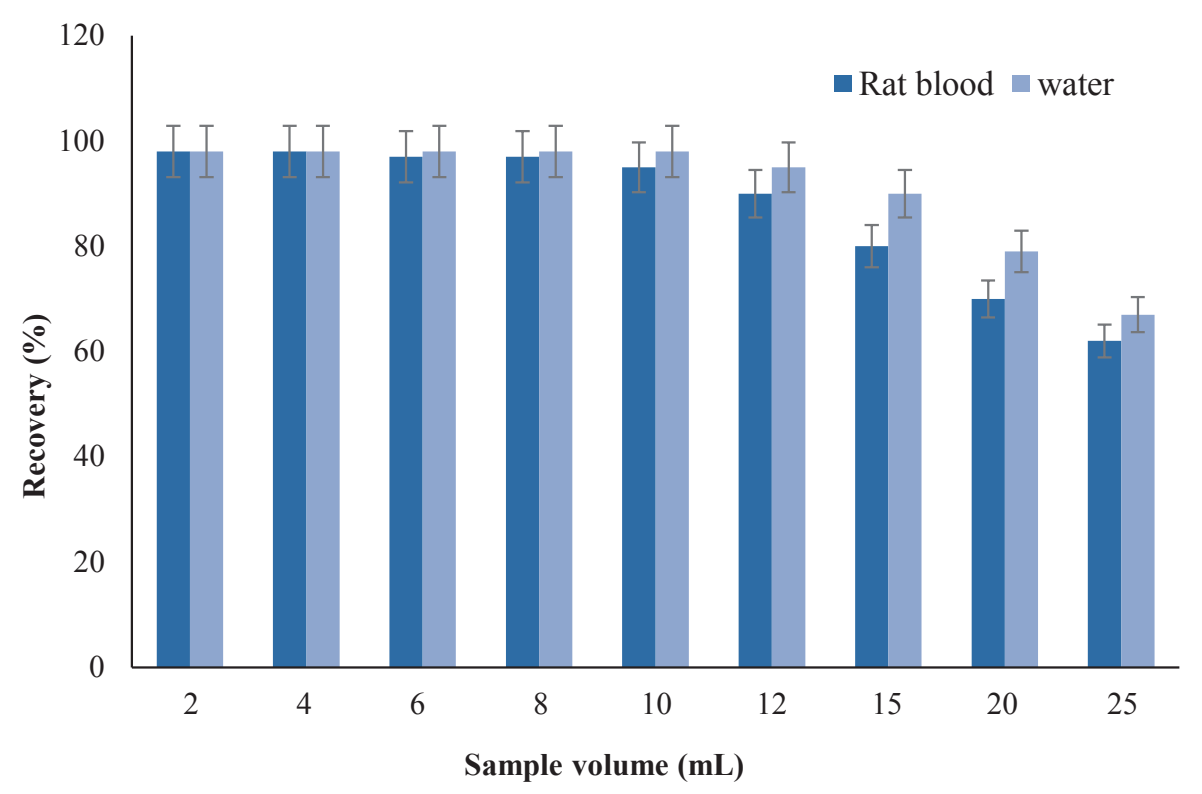

Fig. 6. The effect of sample volume on manganese extraction by IL-LE method 


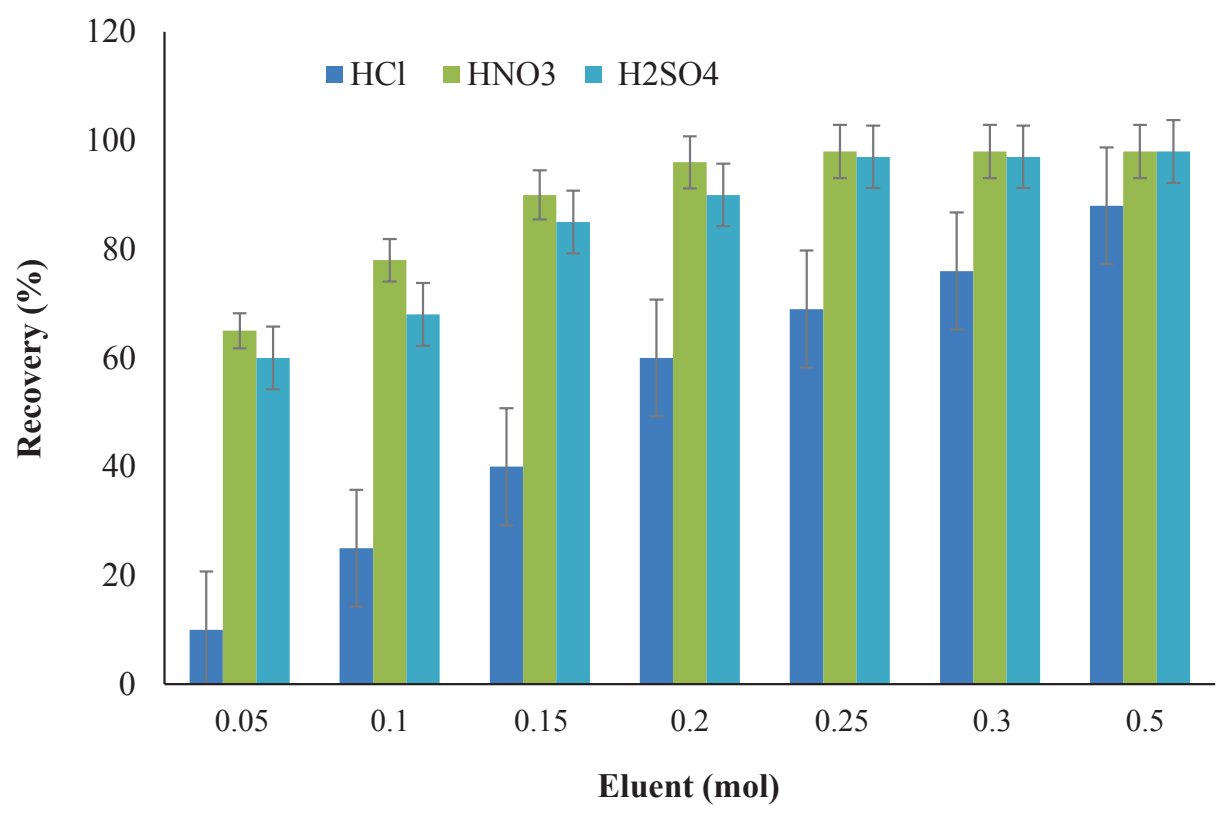

Fig. 7. The effect of eluents on manganese extraction by IL-LE method

\subsection{Discussion of Manganese toxicity}

By procedure, the manganese extracted based on ligand and IL in rat blood samples before determined by the F-AAS. Also, the toxicity of manganese in rat evaluated by chelation therapy with DFO, DFX and DFP before determined by the IL-LE procedure at $\mathrm{pH}=7-7.5$. Due to biologically evaluation, manganese is considered to be an essential metal important to mitochondrial oxidative processes for all living mammals, but may also be toxic at high concentrations [24]. Manganese toxicity seems to be largely due to $\mathrm{Mn}$ induced cellular free radical damage [25]. This hypothesis is based on the potent redox properties of Mn. In our current study uptake of manganese after oral exposure led to elevating RBC, WBC, HGB, PLT and HCT. Furthermore, we observed a clear increase in level of $\mathrm{Mn}$ in blood serum as compared to control. According the previous study, $\mathrm{Mn}$ in the blood compartment may tend to accumulate in the blood cells [26]. RBC count had a significant positive relationship with whole blood manganese [6]. Hemoglobin is a protein containing iron in red blood cells. One red blood cell contains 280 million molecules of hemoglobin. Exposure to Mn during the toxicity period, results increase in both counts of RBC and HGB in whole blood. Manganese leaving the enterocyte and entering the circulation bound to transferrin, may bind to transferrin receptors on erythroid cells. The erythroid cell potentially may incorporate manganese into the porphyrin ring in place of iron, therefore producing a manganese proto-porphyrin instead of hemoglobin [6]. Subsequently, the amount of deformed hemoglobin increases. Hematocrite is the percentage of red blood cells. Therefore, after toxicity with $\mathrm{Mn}$, its behavior is similar red blood cells. The platelet is responsible for blood coagulation. Interestingly, $\mathrm{Mn}$ toxicity increase platelet and the immune system become more active by increasing white blood cell counts. A simple measurement of extracellular Mn such as in serum or plasma may not accurately reflect Mn concentrations in the blood compartment, including blood cells, so whole blood must be analyzed [26]. However, Serum levels of metal are questioned as valid markers of total-body of metal. In any event, our results indicate that Mn can accumulate in serum. In severe case of manganese poisoning, chelation therapy has been recommended in order to reduce the body burden of manganese. Deferasirox, deferipron and desferrioxamine are commonly used chelating agent for treatment of a variety of metal-induced 
toxicities [27, 28], especially treatment of iron. In our previous studies, it has been shown these chelators increase toxin elimination and reducing the body burden of manganese [29, 30]. Also current our study supports the clinical effectiveness of these chelators. Results show that the above chelators are able to return Mn and hematology parameters to nearly normal level of control group. On the other hand, they can determine/separate/extraction of $\mathrm{Mn}$ ions in rat blood samples with high accuracy and precision by F-AAS. The results showed, the DFO as single and combined with DFX and L1 is more effective for extraction of manganese ions. Surprisingly after chelation therapy by combination of DFX and DFO count of WBC increased. There is no satisfactory explanation for this result. However, it is reasonable to postulate that the immune system against the drug increases the white blood cell count.

\subsection{Validation of extraction procedure}

By the ILLE procedure, the separation and determination of $\mathrm{Mn}$ ions in rat blood samples were achieved at $\mathrm{pH}$ from 7.0 to 7.5 . In the real samples such as, water, rat blood and rat serum, the result of manganese were validated by spiking to standard solutions of manganese $(10,20,40.60 \mu \mathrm{g}$ $\mathrm{L}^{-1}$ ) at optimized conditions (Table 5). The results showed us, the efficient extraction for manganese was carried out in real samples based on mixture of DFX, DFO, L1 and [HMIM][PF6] before shaking and centrifuging process. Finally after extraction and back-extraction of $\mathrm{Mn}$ ions, the remained solution was determined by F-AAS by dilution of DW up to $0.5 \mathrm{~mL}$.

\section{Conclusions}

In summary, the speciation and determination of $\mathrm{Mn}$ ions in rat blood samples were achieved by the ILLE procedure at $\mathrm{pH}$ from 7.0 to 7.5. The three chelators, DFX, DFO and L1 used as chelation therapy in rats, then the [HMIM][PF6] added to blood of rats. After shaking, extraction, centrifuging and back-extraction, the Mn values were determined by F-AAS. The linear range and LOD was obtained 25- $180 \mu \mathrm{g} \mathrm{L}^{-1}$ and $6.5 \mu \mathrm{g} \mathrm{L} \mathrm{L}^{-1}$, respectively. Also,

Table 5. Validation of ILLEM for determination of manganese ions in water, whole blood, serum and plasma of rat based on ligand/IL by spiking of real samples $\left(\mu \mathrm{g} \mathrm{L}^{-1} ; \mathrm{n}=8\right)$

\begin{tabular}{lcccc}
\hline Samples & Added & *Found Mn & $\begin{array}{c}\text { *Final concentration Mn } \\
\text { Dilution factor 20 }\end{array}$ & Recovery (\%) \\
\hline Whole blood of rat & ---- & $r 6.54 \pm 1.11$ & $530.80 \pm 25.51$ & ---- \\
& 20 & $45.83 \pm 2.05$ & $916.60 \pm 40.42$ & 96.5 \\
& 40 & $68.12 \pm 2.88$ & $1362.40 \pm 53.72$ & 103.9 \\
\hline Serum of rat & ----- & $13.68 \pm 0.62$ & $273.60 \pm 12.76$ & ----- \\
& 10 & $23.14 \pm 1.12$ & $462.80 \pm 21.73$ & 94.6 \\
\hline Plasma rat & 20 & $33.52 \pm 1.69$ & $670.40 \pm 29.82$ & 99.2 \\
& ----- & $7.68 \pm 0.33$ & $153.60 \pm 6.54$ & ----- \\
& 5 & $12.55 \pm 0.56$ & $251.00 \pm 11.75$ & 97.4 \\
\hline Water & 10 & $17.97 \pm 0.78$ & $359.40 \pm 16.43$ & 102.9 \\
\hline & ---- & $23.88 \pm 1.12$ & ---- & ----- \\
& 20 & $43.64 \pm 1.98$ & ----- & 98.8 \\
\hline
\end{tabular}

$* x \pm t$ s $/$ n at $95 \%$ confidence $(n=8)$

$1 \mathrm{~mL}$ of Whole blood, Serum and plasma diluted with DW up to 20(1:20) 
the results of the current study clearly demonstrated that chronic Mn exposure not only resulted in a marked increase of $\mathrm{Mn}$ concentrations in blood serum, but also caused significant enhances count of RBC, WBC, HGB, PLT and HCT in whole blood. Chelation therapy was effective in returning hematology parameters and $\mathrm{Mn}$ ions to nearly normal level. As well as three chelators are more efficient as combined therapy than single therapy in removing manganese from tissues. Therefore, after basic preclinical research this could be recommended for human administration.

\section{Acknowledgements}

The authors wish to thanks from the head and director of Kerman Neuroscience Research Center, Mohammad Faghihi Zarandi as statistical data analyzer, and Shahid Bahonar University of Kerman Faculty Research for Funding and supporting of this research.

\section{Declaration of interest}

The authors report no conflicts of interest. The authors alone are responsible for the content and writing of this article.

\section{References}

[1] L. Li, X. Yang, The essential element manganese, oxidative stress, and metabolic diseases: links and interactions, Oxid. Med. Cell. Longev., 2018 (2018) 7580707. https:// doi.org/10.1155/2018/7580707

[2] T.V. Peres, M.R.C. Schettinger, P. Chen, F. Carvalho, D.S. Avila, A.B. Bowman, M. Aschner, Manganese-induced neurotoxicity: a review of its behavioral consequences and neuroprotective strategies, BMC Pharmacol. Toxicol., 17 (2016) 57. https:// doi.org/10.1186/s40360-016-0099-0.

[3] N. Reynolds, A. Blumsohn, J.P. Baxter, G. Houston, C.R. Pennington, Manganese requirement and toxicity in patients on home parenteral nutrition, Clin. Nutr., 17 (1998) 227-230. https://doi.org/10.1016/s02615614(98)80064-2.
[4] A.C. Pfalzer, A.B. Bowman, Relationships between essential manganese biology and manganese toxicity in neurological disease, Curr. Environ. Health. Rep., 4 (2017) 223-228. https://doi.org/10.1007/s40572-017-0136-1.

[5] S.L. O'Neal, W. Zheng, Manganese toxicity upon overexposure: a decade in review, Curr. Environ. Health. Rep., 2 (2015) 315-328. https://doi.org/10.1007/s40572-015-0056-x.

[6] E.A. Smith, P. Newland, K.G. Bestwick, N. Ahmed, Increased whole blood manganese concentrations observed in children with iron deficiency anaemia, J. Trace Elem. Med. Biol., 27 (2013) 65-69. https://doi. org/10.1016/j.jtemb.2012.07.002.

[7] Y. Shen, X. Li, D. Dong, B. Zhang, Y. Xue, P. Shang, Transferrin receptor 1 in cancer: a new sight for cancer therapy, Am. j. Cancer. Res., 8 (2018) 916-931. http://www.ncbi. nlm.nih.gov/pmc/articles/pmc6048407/.

[8] X. Ge, F. Wang, Y. Zhong, Y. Lv, C. Jiang, Y. Zhou, D. Li, B. Xia, C. Su, H. Cheng, Y. Ma, F. Xiong, Y. Shen, Y. Zou, X. Yang, Manganese in blood cells as an exposure biomarker in manganese-exposed worker's healthy cohort, J. Trace Elem. Med. Biol., 45 (2018) 41-47. https://doi.org/10.1016/j. jtemb.2017.09.016.

[9] M. Aschner, K.M. Erikson, D.C. Dorman, Manganese dosimetry: species differences and implications for neurotoxicity, Crit. Rev. Toxicol., 35 (2005) 1-32. https://doi. org/10.1080/10408440590905920.

[10] S.J. Fatemi, A. Sh. Saljooghi, F. Dahooee, M. Iranmanesh, M. Golbafan, Chelation of cadmium by combining deferasirox and deferiprone in rats, Toxicol. Ind. Health, 27 (2011) 371-377. http://dx.doi. org/10.1177/0748233710388451.

[11] S.J. Fatemi, F. Khajoee nejad, T. Zandevakili, F. Dahoee balooch, Chelation of cobalt by combining deferasirox, deferiprone and desferrioxamine in rats, Toxin. Rev., 33 (2014) 146-150. https://doi.org/10.3109/155 69543.2014.911749. 
[12] U. Heinz, K. Hegetschweiler, P. Acklin, B. Faller, R. Lattmann, H.P. Schnebli, 4-[3,5-Bis(2-hydroxyphenyl)-1,2,4-triazol1-yl]- benzoic Acid: A novel efficient and selective iron(III) complexing agent, Angew. Chem. Int. Ed., 38 (1999) 25682570. https://doi.org/10.1002/(SICI)15213773(19990903)38:17\%3C2568::AIDANIE2568\%3E3.0.CO;2-C.

[13] T.L. Gerke, B.J. Little, J. Barry Maynard, Manganese deposition in drinking water distribution systems, Sci. Total. Environ., 541 (2016) 184-193. https://doi.org/10.1016/j. scitotenv.2015.09.054.

[14] M. Tuzen, A. Elik, B. Hazer, S. Şimşek, N. Altunay, Poly(styrene)-co-2-vinylpyridine copolymer as a novel solid-phase adsorbent for determination of manganese and zinc in foods and vegetables by FAAS, Food. Chem., 333 (2020) 127504. https://doi.org/10.1016/j. foodchem.2020.127504.

[15] M. Yoon, C. Ring, C.B.V. Landingham, M. Suh, G. Song, T.Antonijevic, P.R. Gentry, M.D. Taylor, A.M. Keene, M.E. Andersen, H.J. Clewell, Assessing children's exposure to manganese in drinking water using a PBPK model, Toxicol. Appl. Pharmacol., 380 (2019) 114695. http:// dx.doi.org/10.1016/j.taap.2019.114695.

[16] WHO, Manganese in drinking water. Background document for development of WHO guidelines for drinking-water quality. World Health Organization, 2011. www.who. int/water_sanitation_health/dwq/chemicals/ manganese.pdf.

[17] C. Kirk, L. Gemmell, C.A. Lamb, N.P. Thompson, C.G. Mountford, B.J. Toole, Elevated whole-blood manganese levels in adult patients prescribed "manganesefree" home parenteral nutrition, Nutr. Clin. pract., 35 (2020) 1138-1142. https://doi. org/10.1002/ncp.10431.

[18] M. Arain, T. Kazi, H. Afridi, J. Ali, A. Spectroscopy, preconcentration of trace level manganese in blood samples of patients with different neurological disorders using a deep eutectic solvent extraction method prior to analysis by flame atomic absorption spectrometry, At. Spectrosc., 38 (2017) 92-98. http://dx.doi.org/10.46770/AS.2017.04.003.

[19] N. Solovyev, M. Vinceti, P. Grill, J. Mandrioli, B. Michalke, Redox speciation of iron, manganese, and copper in cerebrospinal fluid by strong cation exchange chromatography sector field inductively coupled plasma mass spectrometry, Anal. Chim. Acta, 973 (2017) 25 33. https://doi.org/10.1016/j.aca.2017.03.040.

[20] S. Meyer, M. Markova, G. Pohl, T.A. Marschall, O. Pivovarova, A.F.H. Pfeiffer, T. Schwerdtle, Development, validation and application of an ICP-MS/MS method to quantify minerals and (ultra-) trace elements in human serum, J. trace. Elem. Med. biol., 49 (2018) 157-163. https://doi.org/10.1016/j. jtemb.2018.05.012.

[21] B. T1şl1, T.U. Gösterişli, B.T. Zaman, E.G. Bakırdere, S. Bakırdere, Determination of manganese in coffee and wastewater using deep eutectic solvent based extraction and flame atomic absorption spectrometry, Anal. Lett., 54 (2021) 979-989. https://doi.org/10.1 080/00032719.2020.1789871.

[22] D. Rolle-McFarland, Y. Liu , F. Mostafaei, S. E. Zauber, The association of bone and blood manganese with motor function in Chinese workers, Neurotoxicol., 88 (2022) 224-230. https://doi.org/10.1016/j.neuro.2021.12.005

[23] M.R. Pourjavid, M. Arabieh, S.R. Yousefi, A. Akbari Sehat, Interference free and fast determination of manganese(II), iron(III) and copper(II) ions in different real samples by flame atomic absorption spectroscopy after column graphene oxide-based solid phase extraction, Microchem. J., 129 (2016) 259-267. https://doi.org/10.1016/j. microc.2016.07.008.

[24] H. Röllin, A. Mathee, J. Levin, P. Theodorou, F. Wewers, Blood manganese concentrations among first-grade schoolchildren in two South African cities, Environ. res., 97 (2005) 93-99. https://doi.org/10.1016/j.envres.2004.05.003. 
[25] D. Ganini, J.H. Santos, M.G. Bonini, R.P. Mason, Switch of mitochondrial superoxide dismutase into a prooxidant peroxidase in manganese-deficient cells and mice, Cell. Chem. Biol., 25 (2018) 413-425.e416. https:// doi.org/10.1016/j.chembiol.2018.01.007.

[26] Y. Jiang, W. Zheng, L. Long, W. Zhao, X. Li, X. Mo, J. Lu, X. Fu, W. Li, S. Liu, Q. Long, J. Huang, E. Pira, Brain magnetic resonance imaging and manganese concentrations in red blood cells of smelting workers: search for biomarkers of manganese exposure, Neurotoxicol., 28 (2007) 126-135. https:// dx.doi.org/10.1016\%2Fj.neuro.2006.08.005.

[27] M. Khatamifar, Z. Rashidi Ranjbar, S.J. Fatemi, Preparation of deferasirox in nanoscale byultrasonicirradiation and optimization the amount and reaction time parameters, Int. J. Nano. Dimens., 6 (2015) 363-369. https:// doi.org/10.7508/ijnd.2015.04.004.

[28] N. Partovi, M.R. Ebadzadeh, S.J. Fatemi, M. Khaksari, Antilithiatic effect of aqueous and ethanolic extracts of cactus prickly pear in chemically induced urolithiasis in rats, Toxin. Rev., 37 (2018) 166-170. https://doi.org/10.1 080/15569543.2017.1325906.

[29] T. Zandevakili, S.J. Fatemi, V. Sheibani, Chelation of manganese by combining deferasirox, deferiprone and desferrioxamine in male rats as biological model, Toxin. Rev., 34 (2015) 151-156. https://doi.org/10.3109/1 5569543.2015.1074924.

[30] T. Zandevakili, S.J. Fatemi, M. Shabani, K. Esmaeilpour, V. Sheibani, Evaluating the effects of single and combined chelators therapies on spatial learning and memory impairments in chronic manganese poisoning, Toxin. Rev., 35 (2016) 38-46. https://doi.org/ $10.3109 / 15569543.2016 .1141788$. 